\title{
Urban Development Agreement: “METROPOLITAN PERSPECTIVES 2013" \\ The Public - Private Partnership in Urban and Infrastructure Development in the North Area of Reggio Calabria
}

\author{
Raffaele Scrivo ${ }^{1, a}$, Angela Viglianisi ${ }^{1, b}$ \\ ${ }^{1}$ Mediterranea University of Reggio Calabria - PAU - Department of Heritage, Architecture, Urban \\ Planning, Via Salita Melissari - 89124, Reggio di Calabria, Italy \\ araffaele.scrivo@unirc.it, bangela.viglianisi@unirc.it
}

Keywords: Public-Private Partnership, Urban Transformations, Integrated Planning.

\begin{abstract}
The City Plan, can be defined more like an operative program than a plan. In his criteria it is possible to identify a systemic, synergistic and sustanaible approach. The approach was that to define a method to integrate the time with economic and social factors, defining a more large concept of sustainability. The path has involved local stakeholders to understand their need, even often conflictual, between public and private, translating them into selection criteria and go on to apath of selection of actions. These actions will follow on iter on Public - Private partnership, three goals: to decrease public costs, to create a new push effect on investments, to encourage the private stakeholder on process of urban transformation.
\end{abstract}

\section{Introduction}

The National Cities Plan is an important action on mode area-based for the Reggio Calabria city. The approach of this kind of tool consists in an evaluation of effects, of synergies and of partnerships that the expected investments produce on urban territory.

In general case, the aims are to create processes of economic development, to face the social emergencies and resolve the widespread problems of security in the rundown districts.

There are not programs in the ordinary resources, but they are characterized to be episodic in base of valability of public assets those ones generally characterized by need to be spent in short time. The Reggio Calabria city, already in the last ' 80 s, was interested in one of the first Italian order to answer to situations of maximum urban decay and underdevelopment with the Decree Law n. 166 of May 08, 1989, "for the reorganisation and development of the Reggio Calabria city", completely answerd to those feature (at least in the intentions).

This order was based on the "extraordinary need and urgence to adopt immediate measures to the reorganisation and development of the Reggio Calabria city", creating an own fund "to the instant achievement of action about reorganisation" (Decree Lawn 166/89, Preamble).

The need of these tools gives birth two principal requirements:

- Renew the construction sector, that is the 10\% of GDP in Italy.

- Resolving the problem of physical and social decrease of Italian cities.

Adopting this tool, the lawmaker has understood that the urban places need different tools from ordinary to resolve their decreasing problems. Operative tools and dynamicals, that in short time would create processe about economic rebirth and urban transformation.

This approach marks how until now, traditional tools of territorial governance had been unsuitable. Forecasts are still unaspected but exigences have changed.

Nowdays, the city doesn't need to expand itself, but to value his net [1], enrich it with new facilities and technologies. Above all it needs to involve different sectors, productive, social, etc..., to a shared action towards new perspectives of urban transformation. 
There is the need to embroil new economic resources, and to structure expediency systems between public and private stakeholders [2]. This is an aspect that is often omitted in the iter of governament tools. Without any doubt, the continual decrease of expeditive in the aera of public works in the last year has emphasized the crisis in building domain, defining also a negative effect to private investments.

So, in a great crisis, it is necessary to have more operative tools to control the complex and rapid transformations of the cities, but, above all to, answer to new request of urban and extraurban areas. The city does not live by itself, but it lives to all aspects linked to it. Going over the borders until reach the rural areas are often abandoned by politics of sectorial tools.

We need to a bottom-up approach, that involved in the change of the urban transformation all the stakeholders shared.

\section{The City Plan}

The City Plan was introduced with the article 12 of the Decree - Law of June 22, 2012, n. 83 Urgent Measure to the growth of the Country and in two only articles, defined the modus operandi of selection of proposal through simple criterias:

- immediate acclaim of actions;

- capacity and modality of implication of public and private stakeholders and starting of a multiplier effect of public financing to private investments;

- decrease of phenomena of housing voltage, marginalization and social decay;

- improvement of the infrastructural outfit with reference to efficiency of urban transport systems;

- improvement of urban quality, social and environmental net (and control of gasping of a new soil not built up).

So, the City Plan, can be defined more like an operative program than a plan. In his criteria it is possible to identify a systemic, synergistic and sustainable approach [3].

In these cases, the criteria to discern the planning actions also through their acclaim, (that is a predominant criteria) would have inspired to elaborate a simple list of the project actions.

The approach, instead, was that to define a method to integrate the time with economic and social factors, defining a more large concept of sustainability. At first, the actions area of the city was defined by criteria that represented his decay from a functional, infrastructural and social point of view: such as services outfit, urban design and social decay phenomena linked to the security of people.

Then, an analysis about existing projects started, considering his deepening level and bing coherent with goals of the City Plan and the capacity to their own to create a push effect on private investment, considering their value as productions cost and social economic relapses on the context.

As regards to this aspect, the path has involved local stakeholders to understand their need, even often conflictual, between public and private, translating them into selection criteria and go on to apath of selection of actions. These actions will follow on iter on Public - Private partnership, three goals: to decrease public costs, to create a new push effect on investments, to encourage the private stakeholder on process of urban transformation. 
For each private action involved (Social Housing, the Conference Center, Via Marina Redevelopment $)^{1}$, were carried out pre-feasibility studies in which, with the analysis of cash flows, has been verified their economic sustainability and therefore the advantage to invest by a private promoter. The performance indicators used were the net present value (NPV), the internal rate of return (IRR) and payback period (PBP) [4].

The Public - Private partnership for the redevelopment and for the infrastructuration of north area of Reggio Calabria. Methodological Aspects

The methodological path proposed in the paper can be sum up [5]:

- context analysis and present critics and definition of the scope of actions;

- existing projects analysis;

- embroiling of stakeholders and analysis of needs;

- definition of relationships among different stakeholders;

- definition of goals and indicators;

- definition of actions;

- analysis about technical and economic financial feasibility;

- definition of a system of conveniences among different stakeholders.

\section{Case study - The proposal of The City Plan for Reggio Calabria}

The proposal advanced by Municipal Administration, want act a strategy to enforce the future metropolitan role of the city. So for this, there are two strategical point:

- the urban quality, as feature of attractiveness of the city, to add to stop the phenomena of progressive depopulation and, if it possible, change the tendency;

- the localization of function of metropolitan rank as service offered the city to its territory of reference to increase the competitiveness.

The specific objectives set by the city plan were (view Table. 1):

A. To decrease phenomena of housing voltage, marginalization and social decay;

B. To Improve infrastructural outfit even with reference to the improvement of efficiency of urban transport systems;

C. Increasing of public facilities and, improvement of urban quality, social and environmental net, through:

C. 1. improvement of green public and sport structures;

C. 2. settlement services of public utility of metropolitan rank;

C. 3. settlement of new economic activities;

C. 4. requalification of decay in some areas and settlement different social classes.

\footnotetext{
${ }^{1}$ The analysis of cash flows has been carried out on other interventions of the city plan. The negative value of NPV has recommended the procedure Project Financing [4].
} 
Table. 1

\begin{tabular}{|c|c|c|c|c|c|c|}
\hline $\begin{array}{c}\text { Actions } \\
\text { Requalification and realization primary phase } \\
\text { of construction work }\end{array}$ & $\mathrm{X}$ & $\mathrm{X}$ & $\mathrm{X} .1$ & $\mathrm{C} .2$ & $\mathrm{C} .3$ & C.4 \\
\hline Urban Regeneration & $\mathrm{X}$ & & & & & \\
\hline $\begin{array}{c}\text { Social Housing } \\
\text { Road Operas }\end{array}$ & $\mathrm{X}$ & & & & & \\
\hline Facilities for cultural activities & & & $\mathrm{X}$ & & & \\
\hline Structures for Associate/ Cultural services & & & $\mathrm{X}$ & & & \\
\hline Sports facilities & & & $\mathrm{X}$ & & & \\
\hline Construction Fair & & & & $\mathrm{X}$ & & \\
\hline Requalification Umbertine fortifications & & & & $\mathrm{X}$ & & \\
\hline Center conferences & & & & $\mathrm{X}$ & $\mathrm{X}$ & \\
\hline Marina Requalification & & & $\mathrm{X}$ & $\mathrm{X}$ & $\mathrm{X}$ & $\mathrm{X}$ \\
\hline Resetting primary and middle schools & & & & & & $\mathrm{X}$ \\
\hline Hydraulic and reclamation systems & & & & & & $\mathrm{X}$ \\
\hline
\end{tabular}

For each specific objective, the results of the analysis of cash flows and pre-feasibility studies [6] were identified consistent interventions with the criteria for the selection of the city plan.

In this way it was possible to define a system of propriety that led to the selection of interventions, defining the proposal for the Municipality of Reggio Calabria to an investment of $€$ 146.461.218,00, divided into:

1. resources for public actions to financiate with the public fund of National Plan for the Cities: $€ 44.659 .918,00$;

2. resources of other Municipal publics actions, with all financial coverture: $€$ 26.963.500,00;

3. private resources to find (private stakeholder to find by iter of public evidence) for actions in Public - Private partnership to realize on areas of public property: $€$ 52.386.460,00;

4. resources for actions in Public - Private partnership to realize on areas of public property to financiate with funds for the National Plan for the Cities of $30 \%$ of total: $€ 22.451 .340,00$.

The total financialrequired for The Plan of the City of Reggio Calabria is: $€$ 67.111.258, 00.

As regards to private resources to find, Pre-feasibility Studies are made. On these actions, to facilitate the participation on building domain, is foresaw a public co-financial of $30 \%$ to $70 \%$ from private resources. Also, it was verified the real financial sustainability of the actions assumed through the Pre-feasibility studies, the Municipal Administration is going to go on the phase of action and management by innovative tools as Project Financing [7] and/or Leasing of Building.

Naturally the chose of the best tool, will be done by the results of the analysis of cash flows. 


\section{References}

[1] F. Calabrò, L. Della Spina: The cultural and environmental resources for sustainable development of rural areas in economically disadvantaged contexts. Economic-appraisals issues of a model of management for the valorisation of public assets. In: 3rd International Conference on Energy, Environment and Sustainable Development (ICEESD 2013). Advanced Materials Research, Vols. 869-870, (2014), pp 43-48 (C) (2014) Trans Tech Publications, Switzerland doi:10.4028/www.scientific.net/AMR.869-870.43

[2] F. Calabrò, L. Della Spina: The public-private partnerships in buildings regeneration: a model appraisal of the benefits and for land value capture. In: 5nd KKU International Engineering Conference 2014 (KKU-IENC 2014). ADVANCED MATERIALS RESEARCH, Vols. 931932 (2014) pp 555-559 (C) (2014) Trans Tech Publications, Switzerland doi:10.4028/www.scientific.net/AMR.931-932.555, (2014)

[3] M. Florio: La valutazione degli investimenti pubblici, Franco Angeli, Milano (2002)

[4] S. Stanghellini (a cura di): Il negoziato pubblico privato nei progetti urbani: principi, metodi e tecniche di valutazione, dei, Roma (2012)

[5] R. Camagni (a cura di): Economia e pianificazione della città sostenibile, Il Mulino Bologna (1996)

[6] C. Dosi: Gli Studi di Fattibilità degli investimenti pubblici: finalità e requisiti, in Atti del convegno Gli Studi di Fattibilità e la programmazione degli investimenti pubblici, Roma 25-26 novembre 2002

[7] A. Vacca, C. Salustri: Il project financing per le opere pubbliche, Sistemi editoriali SE, Napoli (2003) 